\title{
Peningkatan Pengetahuan dan Ketrampilan Kader Pemantauan Tumbuh Kembang Balita di Posyandu dengan Metode BBM dan Mind Mapping (MM)
}

\author{
Mimin Triyanti ${ }^{*}$, Laksmono Widagdo ${ }^{* *}$, Syamsulhuda $\mathbf{B M}^{* *}$ \\ *) Alumni Magister Promosi Kesehatan Universitas Diponegoro \\ Korespondensi : mimin.triyanti@yahoo.com \\ $\left.{ }^{* *}\right)$ Magister Promosi Kesehatan Universitas Diponegoro Semarang
}

\begin{abstract}
ABSTRAK
Pembinaan kader merupakan sarana penting dalam peningkatan pengetahuan dan keterampilan kader dalam kegiatan Posyandu. Kader yang terampil akan sangat membantu pelaksanaan kegiatan Posyandu. Salah satu unsur yang menentukan keberhasilan peningkatan pengetahuan dan ketrampilan kader adalah penggunaan metode belajar. Tujuan penelitian ini adalah untuk mengetahui perbedaan pengetahuan dan ketrampilan kader setelah mendapatkan pelatihan dengan metode belajar berdasarkan masalah dan metode belajar mind mapping. Penelitian ini merupakan penelitian kuantitatif dengan metode quasi eksperimental, dengan rancangan non randomized control group pretest postest design. Sampel adalah 109 kader Posyandu yang bekerja pada Posyandu strata Madya yang selanjutnya dibagi secara acak menjadi 2 kelompok perlakuan dan 1 kelompok kontrol. Hasil penelitian ini menunjukkan bahwa kader yag mendapatkan pelatihan dengan metode BBM mengalami peningkatan pengetahuan 1,28 lebih banyak dari kelompok MM. Sedangkan peningkatan ketrampilan pada kelompok BBM sebesar 1,43 lebih banyak dari kelompok MM.
\end{abstract}

Kata kunci : pelatihan kader, metode BBM, metode Mind Mapping

\section{ABSTRACT}

Knowledge and Skills Improvement Strategy Cadre in Monitoring Growth Toddler in Posyandu through training of volunteers with Problem Based Learning Method (BBM) and metode Mind Mapping (MM)

Fostering cadres is an important in improving the knowledge and skills of cadres in Posyandu activities. Skills of cadre will greatly assist in implementation of Posyandu. One of the elements that determine the success of increased knowledge and skills of cadres is the use of learning methods. The aim of the research to determine differences in knowledge and skills of cadres after getting training by learning methods based on problems and methods of learning Mind Mapping. This research use quantitative research with quasi experimental methods, the design of non-randomized control group pre-test and post-test design. Samples are 109 health cadres working at Posyandu Madya which are further divided randomly into two treatment groups and one control group. These results indicate that the cadre training with methods of fuel increased 1.28 more knowledge of the MM group. While the improvement of skill in the fuel group of 1.43 more than the MM group.

Keywords: Training of the Cadres, BBM methode, Mind Mapping methode 



\section{PENDAHULUAN}

Posyandu adalah salah satu bentuk Upaya Kesehatan Bersumber Daya Masyarakat (UKBM) yang dikelola dan diselenggarakan dari, oleh, untuk dan bersama masyarakat dalam penyelenggaraan pembangunan kesehatan, guna memberdayakan masyarakat dalam memperoleh pelayanan kesehatan dasar untuk mempercepat penurunan angka kematian ibu dan bayi (Kemenkes RI, 2013).

Kader kesehatan adalah tenaga sukarela yang dipilih oleh masyarakat dan bertugas mengembangkan masyarakat. Dalam hal ini kader disebut juga sebagai penggerak atau promotor kesehatan.(Kemenkes RI,2012)

Peran kader adalah mengambil tanggung jawab, mengembangkan kemampuan, menjadi pelaku, dan perintis serta pemimpin yang menggerakkan masyarakat berdasarkan asas kemandirian dan kebersamaan

Kader harus memahami tugas-tugas pokok kader posyandu. Tugas yang harus dilaksanakan oleh kader posyandu adalah melakukan deteksi dini Pertumbuhan dari berat badan balita yang ditimbang, tindak lanjut bila menemukan gangguan pertumbuhan. Disamping itu kader juga melakukan pemantauan perkembangan balita dan apabila ditemukan gangguan perkembangan, diberikan cara-cara untuk merangsang perkembangan anak, serta melaporkan adanya gangguan perkembangan anak kepada petugas kesehatan untuk diteruskan kepada dokter Puskesmas (Kemenkes RI, 2013)

Pengetahuan adalah hasil tahu dari manusia yang terdiri dari sejumlah fakta dan teori yang memungkinkan seseorang untuk dapat memecahkan masalah yang dihadapinya. Pengetahuan diperoleh baik dari pengalaman langsung maupun pengalaman dari orang lain. Pengalaman adalah guru yang baik merupakan sumber pengetahuan atau suatu cara untuk memperoleh kebenaran pengetahuan, pengalaman pribadi dapat digunakan sebagai upaya memperoleh pengetahuan dengan cara mengulang kembali pengalaman yang diperoleh dalam memecahkan permasalahan yang dihadapi pada masa lalu.(Notoatmojo, 2003)

Keberlangsungan posyandu tidak dapat dipisahkan dari peran kader dalam pelaksanaan posyandu, oleh karena itu pengetahuan dan ketrampilan kader harus selalu ditingkatkan. Hasil survei pendahuluan pada tanggal 14 sampai dengan 16 Oktober 2014 yang dilakukan oleh peneliti dibantu petugas promosi kesehatan puskesmas se Kota Magelang yang melakukan pengamatan pada 5 (lima) Posyandu di Kota Magelang. Dari 25 kader yang diuji coba melakukan penimbangan 
ternyata $13(52 \%)$ kader tidak melakukan penimbangan balita sesuai prosedur dan 11 (44\%) kader tidak dapat mengisi KMS dengan benar serta $78 \%$ diantara mereka belum dapat mendeteksi perkembangan dengan benar. (Dinkes Kota Magelang, 2014)

Dampak kurang dilaksanakannya peran kader posyandu tersebut akan memberikan akibat baik secara langsung maupun tidak langsung. Dampak secara langsung bagi anak, pemantauan tumbuh kembang yang kurang baik menyebabkan tidak termonitornya kesehatan anak, sehingga menimbulkan beberapa permasalahan tumbuh kembang seperti masalah gizi buruk yang selalu saja kita temukan.(Kemenkes RI,2012)

Dari hasil pemantauan tingkat kemandirian Posyandu dalam tiga tahun terakhir di Kota Magelang menunjukkan bahwa strata Posyandu Purnama mengalami penurunan dari $103(52,28 \%)$ di tahun 2012 menjadi $74(37,76 \%)$ di tahun 2013 dan 2014 dan ini masih di bawah target standar Pelayanan Minimal (SPM) sebesar 40\%. Strata Posyandu Pratama dan Madya tahun 2012 masih cukup tinggi $22,33 \%$ (terdiri dari $2,53 \%$ strata Pratama dan 19,79\% strata Madya, sedangkan yang berstrata Mandiri 25,38\% hingga 2014. Gambaran ini merupakan dampak kurang berkembangnya kinerja Posyandu disebabkan oleh pengetahuan dan ketrampilan kader yang masih perlu ditingkatkan (Dinkes Kota Magelang, 2013)

Selama ini kader telah memperoleh pelatihan dasar dan penyegaran tentang kegiatan pelayanan di Posyandu dengan pendekatan konvensional, yaitu pelatihan yang diberikan secara ceramah dan tanya jawab.

Salah satu kelemahan dari metode ini adalah hanya meningkatkan pengetahuan, tetapi tidak meningkatkan ketrampilan peserta latih. Oleh karena itu agar pengetahuan dan ketrampilan kader meningkat sebaiknya perlu memperbaiki teknis pelatihan yang selama ini telah dilakukan dengan metode belajar yang lain (Depkes RI, 2001)

Salah satu unsur yang menentukan keberhasilan peningkatan pengetahuan dan ketrampilan kader adalah penggunaan metode pembelajaran (Depkes RI, 2001), diantara metode belajar tersebut adalah metode BBM dan metode $M M$.

Ditegaskan pula oleh Sanusi bahwa, metode BBM merupakan salah satu alternatif yang dapat dipergunakan mengatasi kelemahan metode Konvensional. Karena metode BBM adalah suatu konsep pendekatan proses belajar mengajar yang bermula dari masalah. Hal ini diperkuat hasil penelitian Edy Sukiarko (2007), bahwa rerata skor ketrampilan BBM lebih tinggi dibandingkan kelompok 
Konvensional, dan terjadi peningkatan rerata skor ketrampilan kader pada kelompok BBM. Artinya pelatihan dengan metode BBM lebih meningkatkan pengetahuan dan ketrampilan kader dalam pemantauan tumbuh kembang pada kegiatan Posyandu dibandingkan dengan metode Konvensional.

Tehnik pelatihan dengan metode BBM adalah para peserta menyajikan bahan pelajaran dengan menjadikan masalah sebagai titik tolak pembahasan untuk dianalisis dan disintesa dalam usaha pemecahan masalah melalui diskusi dan simulasi.

Metode $M M$ adalah metode mencatat kreatif, efektif dalam memetakan pikiran-pikiran yang akhirnya dapat membantu merekam, memperkuat, dan mengingat kembali informasi yang telah dipelajari. $M M$ adalah satu teknik mencatat yang mengembangkan gaya belajar visual, sehingga dengan metode $M M$ pengetahuan yang diperoleh akan lebih langgeng.

Kader sebagai sosok orang dewasa memerlukan metode belajar yang cocok agar proses belajarnya mempunyai dampak pada perubahan perilakunya. Dalam proses belajar yang diterapkan dengan metode BBM dan $M M$ kader lebih dipacu untuk mendalami pengetahuan secara intensif dengan mengaktikan pengetahuan yang dimiliki, mengolah dan mengorganisasikan pengetahuan sehingga pengetahuan dapat bertahan dengan erat dalam sistem penyimpan pengetahuan dan sulit dilupakan.

\section{METODE PENELITIAN}

Penelitian ini menggunakan metode Kuantitatif dengan pendekatan quasy eksperimen, yaitu penelitian yang memiliki perlakuan yaitu peltihan dengan metode BBM dan metode $M M$ dan mengukur dampak dari pelatihan tersebut, dengan jumlah sampel 109 orang kader yang bekerja pada posyandu strata madya di wilayah Kota Magelang, dari bulan Januari 2015 sampai dengan Maret 2015. Tehnik pengambilan data dengan pretest postest menggunakan kuesioner untuk mengetahui tingkat pengetahuan dan lembar observasi untuk mengetahui ketrampilan kader. Data yang sudah dikumpulkan diolah dianalisis secara kuantitatif, dengan analisis univariat dan Analysis of Variance (ANOVA). Analisia univariat adalah analisa yang dilakukan untuk menganalisis tiap variabel dari hasil penelitian (Notoadmodjo, 2005 : 188). Analisa univariat ini berfungsi untuk meringkas kumpulan data hasil pengukuran sedemikian rupa sehingga kumpulan data tersebut berubah menjadi informasi yang berguna, sedangkan uji Analysis of Variance (ANOVA) untuk menguji perbedaan pengetahuan dan ketrampilan antara kelompok kontrol (kelompok 
konvensional) dan kelompok perlakuan (BBM dan $M M$ ). Variabel penelitian adalah variabel bebas pelatihan dengan metode BBM dan MM, sedangkan variabel terikatnya adalah pengetahuan dan ketrampilan kader dalam kegiatan posyandu.

Ada 27 item pertanyaan yang diajukan kepada responden yaitu pengetahuan tentang tumbuh kembang dan pengetahuan tentang pengelolaan Posyandu dan tugas - tugas kader dalam upaya pemantauan tumbuh kembang dengan 2 kemungkinan jawaban. Pada pernyataan positif yaitu "YA" (skor 1) dan "TIDAK" (skor 0). Sebalikya pernyataan negatif jawaban "YA" (skor 0) dan jawaban "TIDAK" (skor 1).

Ada 30 cheklist sebagai panduan observasi ketrampilan responden dalam pemantauan tumbuh kembang balita dengan 2 kemungkinan yang dilakukan "sesuai dengan prosedur" (skor 1) dan apabila tidak sesuai dengan prosedur nilai (skor 0 ).

\section{HASIL PENELITIAN DAN}

\section{PEMBAHASAN}

\section{Analisis Univariat}

Berdasarkan analisis univariat, diketahui bahwa rata-rata umur responden pada kelompok BBM adalah 38,62 tahun tidak jauh berbeda dengan rata-rata umur responden pada kelompok responden dengan pelatihan metode $M M$ yaitu 39,51 tahun, begitu juga dengan rata-rata umur pada kelompok kontrol 38,62 tahun.

Sedangkan persentase tingkat pendidikan dari semua responden semuanya berpendidikan SLTA.

Pada hasil analisis univariat lama menjadi kader menunjukkan bahwa rata-rata lama bekerja responden menjadi kader yaitu 3 tahun 6 bulan, namun demikian kader yang paling lama mengabdi sebagai kader posyandu yaitu 3 tahun 7 bulan pada kelompok BBM, sedangkan pada kelompok $M M$ paling lama menjadi kader aalah 3 tahun 4 bulan.

Sedangkan hasil analisis univariat menganai pelatihan yang pernah diikuti responden sebelumnya, diketaui bahwa $80 \%$ mereka pernah mengikuti pelatihan sebelumnya baik pelatihan dasar maupun pelatihan penyegaran kader.

Hasil analisis univariat informasi tentang tumbuh kembang, 89,2\% responden pada kelompok BBM pernah mendapatkan informasi tumbuh kembang, 63,63\% diperoleh dari petugas kesehatan, 10\% dari media massa dan $50 \%$ diantaranya memperoleh informasi dari buku.

\section{Analisis Uji Anova}

Berdasarkan analisa statistic Analysis Of Variance (ANOVA) terhadap pengetahuan dan ketrampilan kader sebelum dan sesudah pelatihan dapat dilihat 


\section{Pengetahuan}

Bahwa tidak ada perbedaan yang signifikan antara kelompok kontrol dengan kelompok kader yang menggunakan metode BBM maupun kelompok $M M$ sebelum pelatihan, ditunjukkan dengan nilai $\mathrm{p}=0,080$. Data tersebut menunjukkan bahwa baik pada kelompok kontrol, kelompok BBM maupun Kelompok $M M$ sama-sama telah berpengalaman menjadi kader Posyandu meskipun baru sebagian kader yang pernah dilatih, namun secara praktek mereka juga sudah melaksanakannya pada saat kegiatan di Posyandu, sehingga melekat dalam ingatan walaupun terkadang yang mereka kerjakan belum sesuai dengan prosedur.

Perbandingan pengaruh antara pelatihan dengan metode BBM antara sebelum pelatihan (Pretest), postest 1 maupun Postest 2 mengalami peningkatan skor pengetahuan yang cukup tinggi dari pretest ke postest 1 yaitu kenaikan sebesar 2,98 .dari skor nilai pretest 18,16 menjadi 21,14.nilai postes 1 , namun pada postest 2 skor pengetahuan kader menurun 0,38 dari 21,14 nilai Postest 1 menjadi 20,76 postest 2. Hal ini karena dengan Metode BBM tidak hanya sekedar memberikan materi secara ceramah dan tanya jawab saja tetapi lebih banyak melibatkan peran aktif dari para kader dengan menggunakan diskusi, simulasi dan role play serta melakukan pendampingan / tutorial,sehingga dengan pelatihan dengan Metode BBM ini mampu meningkatkan pengetahuan kader sebesar 2,6. Namun pada postest ke 2 (dua), mengalami penurunan skor pengetahua 0,38 hal ini berarti ada pengendapan pengetahuan setelah tutorial 1 (satu) bulan selama 1 bulan. Sesuatu yang dipelajari akan membentuk pengetahuan, seringkali pengetahuan tersebut terlupakan. Ada beberapa sebab seseorang yang telah memperoleh pengalaman tetapi sulit diingat, menurut Purwanto seseorang cenderung lupa karena tergantung pada sesuatu yang diamati, situasi dan proses pengamatan berlangsung serta waktu (Muhibin .S, 2004)

Pada pelatihan dengan metode BBM peserta lebih banyak dilibatkan untuk berpartisipasi aktif sehingga kader akan mempunyai daya ingat yang lebih baik, karena lebih aktif melibatkan peserta dalam kegiatan praktek. Disamping itu ada kegiatan tutorial atau pendampingan dalam diskusi sehingga memacu kreatifitas kader. Dalam hal ini peran Tutor memfasilitasi dengan memberikan rambu-rambu atau kode bila terjadi kemacetan dalam diskusi sehingga metode BBM ini dinilai lebih efektif untuk mempertahankan pengetahuan kader, apalagi dalam waktu yang relatif singkat.

Sedangkan pada kelompok $M M$ terdapat juga peningkatan skor pengetahuan walaupun tidak setinggi pada kelompok 
BBM yaitu dengan nilai pre test 19,29 postest 1(satu) 20,57 dan postest 2 (dua) 19,14. Pada Postest 2 tidak terjadi peningkatan skor pengetahuan tetapi justru terjadi penurunan pengetahuan sebesar 1,43 , tetapi skor pengetahuan postest ke pretest 2 terjadi peningkatan walaupun tidak setinggi skor pretest ke postest 1 . Penurunan skor pengetahuan pada postest 2 metode $M M$ ini merupakan metode mencatat kreatif, efektif dengan memetakan pikiran-pikiran kita jadi hanya peserta yang kreatif yang mampu mengikuti pelatihan dengan metode $M M$ ini.

Selisih skor pengetahuan kader pada kelompok BBM dari pre test ke post test 1 sebesar 2,98 artinya bahwa dengan menggunakan Metode Belajar Berdasarkan Masalah dalam waktu 2 (dua) hari mampu meningkatkan skor pengetahuan kader sebesar 2,98. Sedangkan selisih skor pengetahuan kader post test 1 ke postest 2 terjadi penurunan sebesar 0,38 artinya terjadi pengendapan pengetahuan sebesar 0,38 dalam waktu 1 (satu) bulan . Ini berarti bahwa kegiatan pendampingan / tutorial yang dilakukan sekali seminggu selama satu bulan setelah pelatihan mampu mempertahankan pengedapan pengetahuan kader Posyandu dalam pemantauan Tumbuh Kembang Balita di Posyandu.

Skor pengetahuan kader posyandu pada post test 1 (yang dilakukan segera setelah pelatihan) antara kelompok BBM dan Kelompok $M M$ dengan $\mathrm{p}=0,080$, artinya tidak ada perbedaan yang signifikan, artinya pengetahuan kader sebelum pelatihan baik dari kelompok Belajar BBM dan Metode $M M$ mempunyai karakteristik yang sama. Namun berbeda halnya pada skor pengetahuan kader Posyandu pada post test 2 sebesar $\mathrm{p}=0,000$. menujukkan adanya perbedaan yang siginfikan. Artinya antar Metode BBM dan Metode $M M$ sama-sama mampu meningkatkan pengetahuan kader Posyandu dalam pemantauan Tumbuh Kembang balita di Posyandu. Pada dasarnya pengetahuan kader Posyandu dalam pemantauan kumbuh kembang di Posyandu baik pada kelompok BBM maupun kelompok $M M$ meningkat setelah mendapatkan pelatihan. Namun peningkatan tertinggi terjadi pada kelompok yang mendapat pelatihan dengan Metode BBM. Dengan menggunakan metode BBM terjadi penurunan skor pengetahuan sebesar 0,38 lebih rendah daripada dengan metode $M M \quad$ yaitu sebesar 1,43, artinya pengendapan pengetahuan lebih banyak dengan menggunakan metode BBM, dengan kata lain kalau dengan metode BBM kader akan lebih mudah mengingat dari materi pelatihan yang telah disampaikan.

Pada Postes 1 antara kelompok Metode BBM dan Metode $M M$ sama-sama meningkatkan pengetahuan secara signifikan, dan tidak terdapat perbedaan 
antara kedua metode tersebut, karena kelompok BBM dan Kelompok $M M$ samasama lebih banyak melibatkan keaktifan peserta, artinya dengan psikomotor mampu menguatkan kognitif meskipun hanya sebagian kecil mendapat metode ceramah.

Selesai Post Test 1 (satu), baik pada kelompok BBM maupun kelompok $M M$ diberikan waktu satu bulan untuk dilakukan evaluasi (Post test 2), Baik pada kelompok BBM maupun kelompok $M M$ selama satu bulan dilakukan kegiatan pendampingan 1 tutorial sebanyak 4 (empat) kali yakni setiap minggu 1(satu) kali, untuk 2 (dua) minggu pertama membahas skenario kasus yang ada dalam modul untuk didiskusikan tiap kelompok dengan topik permasalahan yang berbeda mulai dari mengumpulkan data, menganalisis, mencari alternatif pemecahan masalah sampai dengan rencana tindakan yang akan dilakukan, masing masing kelompok didampingi oleh seorang fasilitator yang selalu menggarahkan dan memberikan saran atau masukan,sehingga pembahasan yang dilakukan tidak menyimpang dari topik permasalahan yang mereka ambil.

Pada kelompok $M M$ juga dilakukan pendampingan selama satu bulan seminggu satu kali tetapi pembahasan kasusnya berdasarkan permasalahan yang ditentukan sendiri oleh kader berdasarkan alur pikir yang mereka kembangkan.
Hasil kegiatan tutorial/ pendampingan pada kelompok BBM maupun $M M$ dapat dilihat pada hasil uji beda skor pengetahuan post tutorial, hasilnya menunjukkan $\mathrm{p}=0,000$ yang berarti bahwa ada perbedaan yang signifikan antara pengetahuan setelah tutoril dengan metode BBM dan Metode $M M$, yang mana pada pelatihan dengan Metode BBM mendapatkan skor nilai rata-rata $(20,76)$ lebih tinggi daripada skor nilai rata-rata kelompok $M M(19,14)$

Keadaan ini menunjukkan bahwa kegiatan pendampingan tutorial dalam pemantauan tumbuh kembang di Posyandu yang dipandu oleh bidan dan petugas Promosi kesehatan Puskesmas mampu mempertahankan pengetahuan kader posyandu.

Penerapan metode BBM dalam penelitian ini adalah metode belajar dengan pemecahan masalah yang dititik beratkan pada masalah sebagai inti pembahasan untuk dianalisis dalam upaya mencari alternatif pemecahan masalah dalam rangka pemantauan tumbuh kembang balita di posyandu, dengan pengalaman belajar secara mandiri. Belajar berdasarkan masalah adalah metode pembelajaran yang sejak awal peserta dihadapkan pada suatu masalah, kemudian diikuti oleh proses pencarian informasi yang bersifat studentcentered learning (Harsono, 2004) 
Mengingat peran kader bukan saja sebagai pelaksana pemantauan tumbuh kembang di posyandu tetapi lebih kepada penjaringan kasus gizi buruk, maka perlu pelatihan yang lebih efektif yaitu dengan metode BBM, tujuannya agar dapat meningkatkan pengetahuan dan mempertahankan pengetahuan lebih lama, karena pengetahuan atau kognitif merupakan domain yang sangat penting bagi pembentukan tindakan seseorang. Perilaku yang didasari pengetahuan, kesadaran dan sikap yang positif maka tindakan tersebut akan bersifat langgeng (Long Lasting) atau sebaliknya (Notoatmodjo, 2003)

\section{Keterampilan Kader}

Hasil penelitian ini menunjukan bahwa skor ketrampilan kader Posyandu dalam upaya pemantauan kumbuh kembang di Posyandu sebelum pelatihan diperoleh nilai rata-rata keterampilan pada kelompok kontrol sebanyak 20,08, nilai rata-rata keterampilan kader yang menggunakan metode BBM sebanyak 20,30 dan ketrampilan sebelum pelatihan dengan metode $M M$ yaitu 19,37. Berdasarkan hasil uji beda diperoleh nilai p-value 0,212 > 0,05 . Hal ini berarti bahwa tidak ada perbedaan antara ketrampilan respoden sebelum pelatihan dengan menggunakan metode BBM dengan sebelum pelatihan menggunakan metode $M M$. Artinya baik pada kelompok kontrol, kelompok BBM maupun kelompok $M M$ mempunyai ketrampilan yang sama sebelum dilakukan pelatihan.

$$
\text { Sedangkan nilai rata-rata }
$$

Ketrampilan setelah pelatihan post test 1 pada kelompok kontrol 20,24, kelompok BBM 24,95 dan nilai ketrampilan setelah pelatihan dengan metode $M M$ yaitu 23,60. Berdasarkan hasil uji beda diperoleh nilai pvalue $0,000<0,05$. Hal ini berarti bahwa ada perbedaan antara ketrampilan respoden setelah pelatihan post test 1 antara kelompok kontrol dengan kelompok yang menggunakan metode BBM maupun kelompok yang menggunakan metode $M M$.

Perbandingan skor ketrampilan sebelum pelatihan dan setelah pelatihan terjadi peningkatan rata -rata yang cukup tinggi pada pelatihan Metode BBM baik setelah pelatihan maupun setelah tutorial.

Sedangkan pada kelompok $M M$ terjadi peningkatan skor rata- rata 4,23 setelah pelatihan, namun setelah tutorial terjadi penurunan 0,97 , hal ini karena pada kelompok $M M$ kader mengalami kesulitan dalam menentukan inti masalah sebagai tema utama dalam pembuatan $M M$, sehingga tutor harus lebih aktif lagi mendampingi kader dalam menentukan suatu permasalahan, menganalisanya, sampai menentukan rencana tindakan. .

Suatu ketrampilan dikata baik dan berhasil apabila tingkat kepatuhannya 
mencapai $80 \%$ atau lebih. Meskipun perolehan hasil penelitian ini pada saat pre test untuk kelompok BBM dan $M M$ mempunyai nilai ketrampilan yang sama namun setelah pelatihan maka skor ketrampilan pada kelompok BBM meningkat menjadi 24,69 sedangkan pada kelompok $M M$ menjadi 23,60,kemudian setelah postest 2 untuk kelompok BBM meningkat lagi menjadi 26.00 artinya semakin dikerjakan berulang ulang maka akan makin mengasah ketrampilan sehingga akan semakin meningkat, sedangkan pada kelompok $M M$ menurun menjadi 22,63, artinya bahwa pelatihan yang diberikan dengan $M M$ dalam pemantauan tumbuh kembang di Posyandu belum mampu meningkatkan ketrampilan kader. Sedangkan perubahan skor rata-rata nilai ketrampilan sebelum pelatihan sampai sesudah pelatihan meningkat 4,23 , namun skor ketrampilan setelah tutorial menurun sebesar $(-0,97)$.

Hasil penelitian tersebut memberikan gambaran bahwa pelatihan kader Posyandu dengan metode BBM dapat meningkatkan ketrampilan kader posyandu secara bermakna, Hasil penelitian ini didukung oleh pernyataan Kurrachman (2003), bahwa pelatihan dengan metode ceramah yang disertai diskusi, simulasi dan praktek akan meningkatkan ketrampilan mahasiswa dalam kegiatan pengukuran status gizi balita di Posyandu.
Kemampuan kader dalam menerapkan ketrampilan, terbentuk setelah proses pelatihan dan pendampingan secara terus menerus, Ketika menemukan masalah dalam pemantauan pertumbuhan dan perkembanagn di Posyandu, mulai dari ketrampilan menimbang, menentukan perkembangan sesuai tahap perkembangan sesuai dengan usia, ketrampilan pengisian KMS, pemberian penyuluhan sesuai hasil KMS dan pengisian SIP Posyandu sesuai dengan standar, sehingga apabila ditemukan kesalahan prosedur pada pemantauan pertumbuhan dan perkembangan di Posyandu segera dapat dibenahi dan tidak berlarut- larut.

Memaksimalkan kegiatan pelayanan di Posyandu dengan menghadirkan seluruh balita yang ada di wilayah kerjanya untuk selalu membawa balitanya ke Posyandu, akan membuat kader menjadi lebih trampil dalam menjalan kegiatan di Posyandu. Di samping itu ada beberapa kader senior yang bisa membantu lebih banyak mengeluarkan ide dalam mencari solusi pada permasalahan yang memang sering terjadi di Posyandu

Sesuatu yang pernah dipelajari akan membentuk pengetahuan dan ketrampilan, tetapi sering kali terlupakan karena tergantung sesuatu yang diamati, situasi dan proses pengamatan berlangsung selang waktu. Oleh karena pengaruh lamanya waktu sejak pemaparan sampai dengan post 
test 2 (dua) tidak ada kegiatan yang menunjang ketrampilan maka retensi ketrampilannya pun cenderung menurun dari waktu ke waktu (Depkes RI, 2001).

Pelatihan dengan metode belajar berdasarkan masalah terbukti lebih meningkatkan keterampilan kader Posyandu, baik dalam jangka pendek maupun jangka panjang bila dibarengi dengan kegiatan pendampingan / tutorial yang terjadwal sehingga kader mampu menginventarisir masalah yang ada, membahas dan mengatasi dengan segera apabila detemukan masalah yang berkaitan dengan prosedur pemantauan tumbuh kembang di Posyandu. Pernyataan ini diperkuat oleh Notoatmojo, (1993) bahwa proses pendidikan atau pelatihan menurutnya bahwa suatu sikap belum tentu terwujud dalam praktek atau tindakan, masih diperlukan kondisi tertentu yang memungkinkan terjadinya perubahan sikap menjadi praktek. Kondisi tersebut antara lain tersedianya fasilitas untuk belajar yaitu peserta diberi kesempatan untuk melihat, mendengar dari orang lain, melakukan ketrampilan tersebut dan diberikan kesempatan untuk melakukannya sendiri seperti yang diterapkan pada kelompok BBM.

Aplikasi Metode BBM

dikembangkan untuk membantu peserta mengembangkan kemampuan berpikir berbagai pemecahan masalah da ketrampilan intelektual, belajar tentang berbagi peran orang dewasa melalui pelibatan mereka dalam pengalaman nyata atau simulasi, dan menjadi pembelajaran yang otonom dan mandiri, sehingga dengan demikian akan terwujud prestasi belajar yang semakin meningkat. Oleh karena itu pembelajaran hendaknya juga menitik beratkan pada peningkatan pemahaman terhadap berbagai suatu konteks bagi siswa untuk belajar tentang cara berfikir kritis dan ketrampilan pemecahan masalah, serta untuk memperoleh pengetahuan dan konsep yang esensial dari suatu materi pembelajaran.

Oleh sebab itu agar efektif untuk mendapatkan hasil yang lebih baik dan tetap menjaga retensi pengetahuan dan ketrampilan serta mencegah terjadinya penurunan retensi pengetahuan pada kader dalam pemantauan tumbuh kembang di Posyandu, maka sebaiknya menerapkan pelatihan dasar atau penyegaran kader dengan metode BBM. Untuk menindaklanjuti hasil pelatihan supaya pengetahuan maupun ketrampilan kader langgeng, maka kegiatan pemantauan sekaligus pembinaan secara rutin, oleh petugas kesehatan, bimbingan dan supervisi dari petugas kesehatan akan berpengaruh terhadap peningkatan pengetahuan dan ketrampilan kader. Pelatihan dengan metode BBM diakui mempunyai keunggulan dapat meningkatkan 
pengetahuan dan ketrampilan kader lebih tinggi karena peserta lebih leluasa secara mendiri mencari alternatif pemecahan masalah dengan mengembangkan kemampuan berfikir secara kreatif dan menyeluruh serta dimungkinkan pengembangan materi semaksimal mungkin sesuai dengan bahan ajaran yang telah diberikan. Akan tetapi pelatihan dengan metode BBM juga mempunyai kelemahan apabila peserta tidak mampu untuk mengembangkan bahan ajaran, maka proses belajar akan menjadi tidak menarik, membutuhkan fasilitator yang terampil dan menguasai materi, pengajar yang banyak, biaya pelaksanaan yang cukup mahal, waktu yang digunakan lama dan apabila bahan ajar yang tersedia terbatas, maka peserta kurang dapat mengembangkan materi pelatihan, serta masalah yang dibahs tingkat kesulitannya disesuaikan dengan tingkat kemampuan berpikir peserta.

Sebaliknya metode $M M$ mempunyai kelebihan dalam $M M$ membuat otak manusia ter-eksplor dengan baik,dan bekerja sesuai fungsinya, penyelenggaraan mudah dan murah, menggunkan kertas dan pensil warna-warni untuk lebih menghidupkan tema dan sub-sub tema yang akan dikembangkan. Adapun kelemahan pada metode $M M$ ini adalah hanya akan berjalan dengan baik apabila pesertanya aktif, sebaliknya tidak akan terjadi proses apabila pesertanya kurang antusias, kader dituntut untuk berfikir 2 (dua) kali yaitu berfikir bagaimana cara mengembangkan alur pikir dalam bentuk tulisan dan berpikir untuk mencari tema dan sub-sub tema sebagai alternatif pemecahan masalah, lama kelamaan kader mengalami kejenuhan dan akhirnya menjadikan suatu hal yang tidak menarik, serta lebih mudah untuk dilupakan (Ewles LT \& Simnett .I, 1991)

Selain itu hanya sebagian kecil yang nampaknya dapat diingat pada akhir pertemuan dan akan berkurang dalam beberapa hari, sehingga pengetahuan dan ketrampilan yang diperoleh tidak akan langgeng (Mass .LT \& Husodowijaya, 1991).

\section{SIMPULAN}

Berdasarkan hasil penelitian dan pembahasan dapat disimpulkan beberapa hal sebagai berikut : tidak ada perbedaan yang bermakna antara pengetahuan sebelum dan setelah pelatihan dengan metode konvensional. Pada kelompok BBM terjadi peningkatan pengetahuan 1,28 lebih banyak daripada keompok $M M$.

Tidak ada perbedaan ketrampilan sebelum dan setelah pelatihan dengan menggunakan metode belajar konvensional, akan tetapi pada kelompok pelatihan dengan metode BBM terjadi pengendapan ketrampilan lebih banyak dibandingkan dengan yang menggunakan metode $M M$, yakni pada kelompok BBM terjadi 
penurunan ketrampilan sebesar 0,97 sedangkan pada kelompok $M M$ terjadi penurunan sebanyak 1,43 .

Sehingga pelatihan dengan metode BBM lebih meningkatkan pengetahuan dan ketrampilan dan mempertahankan pengetahuan dan ketrampilan kader lebih lama dibandingkan dengan metode $\mathrm{MM}$ maupun metode konvensional.

\section{KEPUSTAKAAN}

Buzan T. 2010. Mind Map untuk Meningkatkan Kreatifitas. Gramedia Pustaka Utama. Jakarta.

Departemen Kesehatan R.I. 2001.Pelatihan Management of Training (MOT). Balai Pelatihan Kesehatan Gombong. Departemen Kesehatan R.I.Jakarta.

Direktorat Bina Gizi Masyarakat; Depkes RI dan Fakultas Kesehatan Masyarakat Universitas Indonesia.1998. Program Perbaikan Gizi Keluarga di dalam Posyandu. Departemen Kesehatan RI. Jakarta.

Departemen Kesehatan RI. 2012. Buku Kesehatan Ibu dan Anak; Gerakan Pemantauan Tumbuh Kembang Anak. Departemen Kesehatan RI. Jakarta.

Departemen Kesehatan RI. 2006. Modul Pelatihan Peningkatan Peran Serta Masyarakat dalam Kegiatan Posyandu. Departemen Kesehatan RI. Jakarta.

Diana FW. 2008. ABC of Learning and Teaching in Medicine. BMJ. 2008; 326: 18-20
Djamarah SB dan Zain A.2006. Strategi Belajar Mengajar. Penerbit Rineka Cipta, Jakarta.

Junaedi P. 1990. Kader dalam Program Upaya Perbaikan Gizi Keluarga; Keluaran, Kemampuan dan Popularitasnya. Prosiding KPIG dan Kongres VIII. Persagi. Jakarta.

Kementerian Kesehatan RI. 2012. Instrumen Stimulasi Deteksi dan Intervensi Tumbuh Kembang. Kementerian Kesehatan RI. Jakarta.

Kelompok Kerja Nasional Posyandu Pusat. 2012. Kurikulum dan Modul Pelatihan Kader Posyandu. Kementerian Kesehatan RI. Jakarta.

Lockwood D.1994. Desain Pelatihan Efektif Bagi Supervisor dan Manajemen Madya. Gramedia Pustaka Utama. Jakarta.

Mukti AM.1996. Menjaga Mutu Pelayanan Bidan Desa, Penerapan Metode Belajar Berdasarkan Masalah. Pusat Penelitian Kependudukan Universitas Gadjah Mada. Yogyakarta.

Notoatmodjo S. 2003. Pengantar Pendidikan Kesehatan dan Ilmu Perilaku Kesehatan. Andi Offset. Yogyakarta.

Nurhadi, Yasin, dan Senduk. 2004. Kontektual dan Penerapannya dalam KBK. Universitas Negeri Malang. Malang.

Pusat Pendidikan dan Pelatihan Kesehatan.2002. Petunjuk Teknis Pelaksanaan Jabatan Fungsional Widyaiswara. Pusat Pendidikan 
dan Pelatihan Departemen Kesehatan RI. Jakarta.

Pedersen, Susan and Williams.2004. Comparison of Assessment Practices and Their Effects on Learning and Motivation in a Student- Centered Learning Environment. Journal of Educational Multimedia and Hypermedia. 2004; 5 : 4-8.

Pusat Pendidikan dan Pelatihan Kesehatan.2002. Petunjuk Teknis Pelaksanaan Jabatan Fungsional
Widyaiswara. Pusat Departemen Kesehatan RI. Jakarta.

Santosa PB dan Ashari. 2005.Analisis Statistik dengan Microsoft Excelt dan SPSS. Andi. Yogyakarta.

Sugiyono. 2006. Metode Penelitian Kuantitatif Kualitatif $\mathrm{R}$ dan $\mathrm{D}$. Alfabeta Bandung.

Silberman M. 2003. Active Learning 101 Strategi Pembelajaran Aktif.Insan Madani. Yogyakarta. 